\title{
STUDENTS' EMOTIONAL LITERACY IN THE DISCOURSE OF THE CONTEMPORARY SCHOOL IN SERBIA
}

Dr. Djermanov Jelena, Department of Pedagogy, Faculty of Philosophy, University of Novi Sad, Serbia

E mail: jdjer@ff.uns.ac.rs

Dr. Marić Jurišin Stanislava, Department of Pedagogy, Faculty of Philosophy, University of Novi Sad, Serbia E mail: stashamaric@ff.uns.ac.rs

ARTICLE INFO

Original Research

Received: May, 07.2018.

Revised: May, 25.2018.

Accepted: June, 11.2018.

doi:10.5937/ijcrsee1802001D

UDK

159.942-057.874(497.11)

\section{Keywords:}

emotional literacy,

affective dimension of education,

students,

teachers,

school.

\begin{abstract}
A B S T R A C T
The results of the research on the emotional literacy of students are presented in this paper. The primary goal of the research was to examine the general level and characteristics of the emotional literacy profile. The secondary goal was to determine the similarities and differences in levels of emotional literacy between pupils in relation to their gender and age. "Emotional awareness questionnaire" was used on the sample of 335 students of both sexes and two age groups (primary school pupils aged 14-15 years and high school students of 18-19 year). The research was descriptive, nonexperimental and exploratory. The data obtained by the study were analyzed using the statistical package SPSS. The results of statistical descriptions of the empirical profile suggest that the general level of students' emotional literacy can be classified as average. Analyzes of differences related to gender and age on individual profile components, showed that the gender differences were statistically significant ( $\mathrm{p}<.001)$ on all components ("emotional numbness," "empathy" and "interactivity"), while age differences were significant on the components: "differentiation of emotions" and "empathy" ( $p<.001)$. The obtained findings were discussed in the context of the starting reference model of research. Recommended and needed future steps are the pedagogical monitoring of emotional development of young people, systematic influence on the development of their emotional competences and a far more active role of the school in the development of the emotional literacy of both students and teachers.
\end{abstract}

(C) 2018 IJCRSEE. All rights reserved.

\section{INTRODUCTION}

The question of the affective dimensions of the educational process and the emotional literacy of pupils and teachers is a topic that contemporary education was focused on only in recent years.

Before this, the approach to emotions in an educational context could be labeled as "emotionally blind", although it has long been known that emotions are factors that influence

Corresponding Author

Dr. Marić Jurišin Stanislava, Department of Pedagogy, Faculty of Philosophy, University of Novi Sad, Serbia E mail: stashamaric@fff.uns.ac.rs

\section{(c) (i) $\Theta$}

This work is licensed under a Creative Commons Attribution - NonCommercial - NoDerivs 4.0. The article is published with Open Access at www.ijcrsee.com the overall functioning of a person, and have an important, often crucial, role in interpersonal relations, motivation and learning. As early as 1930s, Vygotsky (1986) has stated in his learning theory that emotions have key roles in employing cognitive skills, learning and development process. Social and emotional factors have wide range of impacts from motivation for learning, remembering previously learnt knowledge and skills to logical thought (Elias, 2006; Oksuz, 2016; Park, 1999).

In recent years, many authors have contributed with their work to clearer understanding of the importance of emotional competences for the level of life success and well-being of man. However, the strongest impact on the (re)affirmation of emotion research in all academic areas, has been achieved by research in the field of neuroscience (Immordino-Yang, 2011; Immordino-Yang and Damasio, 2011).

Concerning the promotion of the "emo- 
tional concept" in teaching and learning, the merits are most often attributed to Goleman and his, already famous point of view, according to which emotional competences are not inborn, but can be learned; they are developed through experiences and can be developed, practiced and learned, like any other subject (Goleman, 2006).

New psychological literature offers more models and theories of emotional intelligence (Ability model, Trait model, Mixed model).

These models differ in their conceptualization and operationalization of key terms, as well as in the way they study and measure these terms. Therefore, Park (1999) considers it desirable to first disclose the differences between the related, most frequently used constructs: emotional intelligence and literacy.

Emotional intelligence is a potential (predisposition) for emotional fluency, while emotional literacy represents the constellation of skills, strategies and tools that we adopt and develop to become truly emotionally fluent (Bocchino, 1999). Park, 1999 states that emotional literacy is the ability to recognize one's own and others' emotions, and to react accordingly. Steiner (2003), widely accepted as the author of the term "emotional literacy", states that an emotionally literate person is able to become aware of their own feelings, whether they are pleasant or unpleasant, and acts in accordance with this knowledge. Therefore, person's perceptions and awareness of their own emotional experience is the central focus on which studies of emotional literacy are directed, as can be concluded from the understanding of the above mentioned and other authors (Orbach, 2000; Park, 1999; Steiner, 2003).

In addition to defining and operationalizing the emotional literacy construct, the second, essentially important question, are the characteristics and possibilities for its development. The belief that emotional literacy can be developed and taught at every age is widely represented in the emergence of the various applicative programs concerning emotional literacy, that are increasingly diverse and numerous worldwide.

Even though the belief that the possibilities for the development of emotional literacy are not limited by age has its foothold in empirical research, it is still considered that learning is best started in childhood (FigueroaSánchez, 2008), as is the case with most other skills such as reading, writing, learning foreign languages, sports... In the context of education, this position is important in various aspects because, according to Steiner (2003), humans start to define their life attitudes early in life and emotional habits depend on them and therefore will very likely accompany the person during her entire life.

The strong influence of the emotional experience on all human activities, and the fact that it plays a significant role in the educational process, not only in actual achievement and learning, but also in the lifelong learning, is documented by many review, systematic and critical studies, meta-analysis and by a large number of empirical quantitative and qualitative researches (Buljubašić-Kuzmanović, 2008; Durlak, Weissberg, Dymnicki, Taylor, and Schellinger, 2011; Elias, 2006; Humphrey, Curran, Morris, Farell, and Woods, 2007; Wells, Barlow and Stewart-Brown, 2003; Zins, Bloodworth, Weissberg, and Walberg, 2004; Zins and Elias, 2006).

In empirical studies, socio-emotional aspects of the family and school environment, interactions with parents, peers, and teachers are the most examined factors in correlation to academic achievement. Recent researches are more focused on the school climate and the specific aspects of the socio-cultural environment of growing up, such as the number of family members, educational style... and their impact on prosocial behavior, willingness to learn and learning ability, sense of security in the school environment, self-actualization, life values and student attitudes (Jennings and Greenberg, 2009; Stepanović and Đermanov, 2015).

Although these studies examine various socio-emotional aspects in relation to different educational outcomes, their findings consistently point to a general pedagogical, developmental-psychological, theoretical postulate that a child can successfully participate in the educational process only when his or her basic needs (in this case the need to express, articulate and regulate emotions), are adequately met (Schutz and Lanehart, 2002). A number of authors point out that it is quite certain that emotions have an impact on learning of cognitive content in schools. These authors argue that emotions are embedded in a series of cognitive processes that are part of the learning process, of attention, memory, decision making, motivation and social functioning, and that rational logical thinking deprived of emotions cannot be adequately used in the real world (Immordino-Yang and Damasio, 2011; Tošić Radev, and Pešikan, 2017).

The latest research into affective dimensions of education provides plenty of evidence 
that the experience of academic (non)success is directly and indirectly related to socio-emotional experiences at school: to the feeling of acceptance or rejection by teachers, peers, isolation experience and various other forms of emotional stress; and that the frequent negative emotional experiences increase the risk of generalized failure, lead to school absenteeism, juvenile delinquency and other problems in dealing with difficulties during life (Zins et al, 2004).

On the other hand, although teachers are aware of the variety of feelings of comfort and discomfort, which accompany their everyday work in the classroom, many experts warn that this field is still not understood adequately. There is a need for the teachers to recognize the connection of their own feelings and emotional competences with the pedagogical climate that they create in the classroom, their work style and the leadership and support they provide to students (Suzić, 2002; Perry and Ball, 2007; Jennings and Greenberg, 2009; Golub and Bohač, 2015).

However, all these findings are slowly and very selectively applied in our educational practice. Emotions in school (in teaching) are still a controversial subject, whose "power" can be productively "used" and unfortunately "abused". The contemporary living conditions put both the teachers and the students in the position to face ever increasing and diversifying challenges, such as accelerated technological development, increasing insecurity and frustration and changes in the field of work. All this changes demand different approaches to education and different concepts of literacy from those of the $20^{\text {th }}$ century (Elias, 2006; Djermanov et al, 2015).

Our research is a contribution for the initial analysis of the level of emotional literacy of students in our country. Our motivation was the intention to contribute to a better understanding of the pedagogical and social importance of the affective dimension of education in the discourse of contemporary school through this research.

\section{MATERIALS AND METHODS 2.1. Research Topic and Purpose}

The topics of this research are the characteristics and levels of students' emotional literacy. The research is based on the Claude Steiner's theoretical model of emotional literacy (2003). The aim of the research was to identify the characteristics of the emotional literacy profile of students related to their sex and age. This aim is concretized through three objectives: (1) To test the level of students' emotional literacy based on profile components from the theoretical model; (2) To examine the differences between the levels of emotional literacy based on the sex of the students; (3) Determine the differences between the levels of emotional literacy based on the age of the students.

\subsection{Research Methods and Techniques}

Descriptive research method and a structured questionnaire survey have been used in this research. "Emotional awareness questionnaire" was used for gathering the data (Steiner, 2003). This instrument is comprised of six subscales; emotional numbness; physical sensations, chaotic primal experience; differentiation of emotions; empathy and interactivity. Emotional awareness was an indicator of the operationalization of literacy components.

Each subscale has six statements (36 items in total) with three response modes (Yes - No - Not Sure). Only positive answers are scored.

The profile of emotional awareness for each examinee was constructed on the basis of partial scores on subscales. According to the typology of the theoretical model, empirical profiles were classified into: profile of low, average and high level of emotional awareness. This research has used four of the six scales in the original instrument: emotional numbness scale (EN); differentiation of emotions (DF); empathy (EM) and interactivity (IA). This instrument has been translated into Serbian language in 2007, as a part of the Steiners' study: „Emotional Literacy; Intelligence with a Heart".

\subsection{Research Sample}

The research was conducted on a sample of two age groups of students, both sexes, in the urban environment $(\mathrm{N}=335)$. The sample consisted of 335 students, of which 164 were primary school pupils, 14-15 years of age, and 171 were grammar school students, aged 1718 years. The distribution of examinees by sex was: 146 male and 189 female. The examinees were students of two primary and two secondary schools in Novi Sad in the Republic of Serbia. 
(IJCRSEE) International Journal of Cognitive Research in Science, Engineering and Education Vol. 6, No. 2, 2018.

Table 1. Sample of the Research

\begin{tabular}{lccc}
\hline Age of children & $\begin{array}{c}\text { Sex of } \\
\text { children }\end{array}$ & $\mathrm{N}$ & $\Sigma$ \\
\hline Primary school & $\begin{array}{c}\text { Male } \\
\text { Female }\end{array}$ & 75 & 164 \\
\hline $\begin{array}{l}\text { Secondary } \\
\text { school }\end{array}$ & $\begin{array}{c}\text { Male } \\
\text { Female }\end{array}$ & $\begin{array}{c}71 \\
\text { Age of children }\end{array}$ & 171 \\
$\begin{array}{l}\text { Primary \& } \\
\text { Secondary }\end{array}$ & Male & 141 & 335 \\
\hline
\end{tabular}

\subsection{Statistical data processing}

Data analysis: After the carried out research, the data were prepared for the statistical analysis. SPSS Program was used for quantitative data processing in order to perform statistical calculations of measures and procedures in the field of descriptive statistics and inferential statistics (frequency, arithmetic mean, standard deviation, $t$-test to test the significance of differences between independent groups of respondents).

\section{RESULTS}

The first task of the research was focused on the level of emotional consciousness of students (emotional literacy). The level of emotional consciousness implicitly indicated the level of emotional literacy as well, because it could not be directly measured, but indirectly through measuring emotional consciousness.

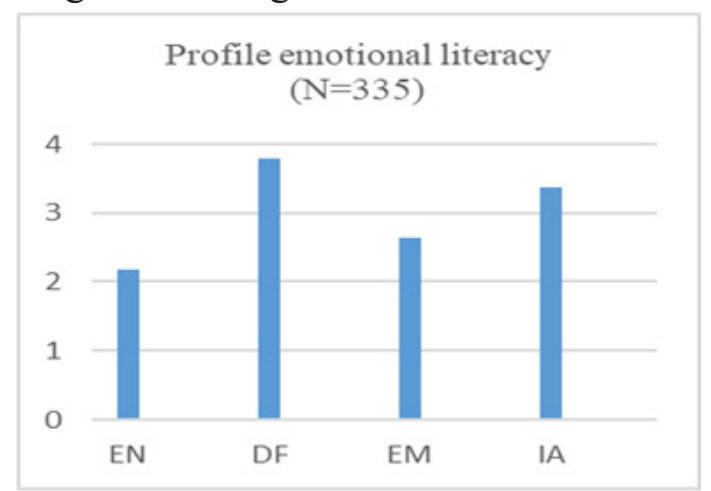
profile

Figure 1. Students' emotional literacy

Based on descriptive result indicators (frequency, average values and partial scores on subscales), we obtained the empirical profile of students' emotional literacy (Figure 1). The profile has characteristics of the theoretical profile of the average level of emotional awareness (Steiner, 2003), which means that examinees aged 14-19, both sexes, exhibit an average level of emotional literacy.

\subsection{The differences of Emotional literacy according to the sex}

Results of the analysis of components of the emotional literacy profile (awareness) based on the sex of the examinees (Table 2) show that differences are statistically significant $(p<0.01)$ in three of the four observed components.

Table 2. Emotional consciousness: Significant differences according to the sex

\begin{tabular}{|c|c|c|c|c|c|}
\hline $\begin{array}{c}\text { Components } \\
\text { Scale }\end{array}$ & Sex & M & $\mathrm{SD}$ & $\begin{array}{l}\text { t-test } \\
\text { value }\end{array}$ & $\mathrm{p}$ \\
\hline \multirow{2}{*}{$\mathrm{EN}$} & Male & 2.60 & 1.27 & \multirow{2}{*}{6.22} & \multirow{2}{*}{.00} \\
\hline & Female & 1.81 & 1.05 & & \\
\hline \multirow{2}{*}{ DF } & Male & 3.59 & 1.31 & \multirow{2}{*}{-2.58} & \multirow{2}{*}{.01} \\
\hline & Female & 3.96 & 1.32 & & \\
\hline \multirow{2}{*}{ EM } & Male & 2.55 & 1.37 & \multirow{2}{*}{-.93} & \multirow{2}{*}{.35} \\
\hline & Female & 2.69 & 1.32 & & \\
\hline \multirow{2}{*}{ IA } & Male & 3.14 & 1.57 & \multirow{2}{*}{-2.87} & \multirow{2}{*}{.00} \\
\hline & Female & 3.60 & 1.32 & & \\
\hline
\end{tabular}

Results (Table 2) were additionally analyzed and interpreted on the subscales of emotional numbness (EO), differentiation of emotions (DE), empathy (EM) and interactivity (IN).

\subsubsection{Differences in the level of emotional numbness $(E N)$ in relation to the sex}

Emotional numbness (EN) is at the very end of the scale of emotional literacy and marks a low emotional awareness.

A high score on this scale is manifested by the absence of emotional reactions, feelings of emptiness, exhaustion, and confusion. People with extremely high results are usually not aware of their emotions. Emotions are "frozen" and inaccessible for consciousness.

Our results on this scale (EN) show that girls generally have significantly lower scores than boys and that these differences are statistically significant $(\mathrm{p}<0.01)$. A relatively high score among the male examinees $(\mathrm{M}=2.60$; $\mathrm{SD}=1.27$ ) on the scale of emotional numbness, is additionally analyzed through the content of individual passages on this scale. The results of our analysis reveal the alarming fact that $50 \%$ of boys have affirmatively answered questions such as: "I can easily kill a small animal, such as a snake or a chicken, and at 
the same time "I do not feel anything special" or "I can be around people who feel physical pain, and that does not upset me", as well as the statement "I cry extremely rarely", where more than $90 \%$ of boys responded affirmatively. The latter could be interpreted in the light of our patriarchal upbringing that "teaches" male children to be strong and not to show their emotions. That was the reason for cold and apparent "superhuman" strength in their responses. It was obvious that male children continued to carry a huge emotional burden, which they should keep to themselves, as they were taught.

\subsubsection{Differences in the level of differentiation of emotions (DF) in relation to the sex}

The second component of the "differentiation of emotions" refers to the recognition and interpretation of one's own and other's emotions. The level of differentiation of emotions shows how much a person is aware of their feelings, whether he or she knows how to recognize them and to determine their intensity, to think about them and to talk with other people about them. Generally speaking, the differentiation of emotions allows regulation, control and adequate expression of emotions. People with a high degree of emotional awareness achieve a high score on this component. Our results on the scale of differentiation show that the examinees of both sexes have very high scores and that girls show a higher degree of differentiation of emotions (Female, $\mathrm{M}=3.96, \mathrm{SD}=1.32$; Male, $\mathrm{M}=3.59, \mathrm{SD}=1.31$ ).

The difference is statistically significant $(p<0.01)$. This data suggests that girls in general have a higher level of "emotional literacy" than boys, since the component of the differentiation of emotions is crucial for the development of higher levels of emotional awareness.

\subsubsection{Differences in the level of empathy $(E M)$ in relation to the sex}

The third analyzed component is "Empathy". Empathy is a specific kind of intuition and it is exclusively related to emotions. Its basic characteristic is the emotional vicarious experience of another person's feelings. It differs from compassion in that compassion is a mental, and empathy is an emotional process. A high score at the empathy scale indicates a high level of emotional awareness

In order to be able to develop empathy, a person needs a high ability to differentiate his or her own emotions, so that he or she could share the emotions of others. Our research has not shown the significant differences in the empathy (EM) levels by sex (Table 2).

Although the examinees have a high score on the differentiation of emotions scale, both sexes report a relatively low level of empathy (Male, $\mathrm{M}=2.55, \mathrm{SD}=1.37$; Female, $\mathrm{M}=2.66, \mathrm{SD}=1.32$ ).

\subsubsection{Sex differences in degree of interaction (IA)}

Fourth component is the "emotional interactivity" (IA). Steiner (2003) says it is "the most sophisticated level of consciousness" (p.48). It is shown through the way of reacting to emotions and understanding the emotional exchanges between people.

Emotional interactivity requires a high level of awareness of one's own and other people's emotions, the estimation of how different emotions affect each other, and the awareness that the interaction of different emotions affects the intensity, dynamics and development of new ones. Interactivity is at the top of Steiner's (2003) scale of emotional awareness, but he does not exclude the possible existence of another component, closer to the full awareness.

Our results (Table 2) show that the examinees of both sexes have high values on this component (Female, $\mathrm{M}=3.60, \mathrm{SD}=1.32$; Male, $\mathrm{M}=3.14, \mathrm{SD}=1.57)$. The differences by sex are statistically significant $(\mathrm{p}<.00)$ and higher among the female examinees.

The data concerning the high scores on this scale, for both groups of examinees and relatively low scores on the empathy scale, motivated us to analyze in more detail the answers on the individual items of the scale. Content analysis of the following items: "People appreciate me because I calm down the situations when the emotions are heated."; "I help people to understand and differentiate their emotions and I'm good at it because I usually understand why they feel them." "When I'm in a room full of people, I can recognize the feelings of that group - excitement, anger, boredom or fear", suggests a possible reason for this unexpected result. We think that students were more focused to their own "I" or "me" position, rather than the content of the state- 
ment itself (I help others, I can understand, people appreciate me). The striking similarity in the scores of differentiation and interactivity scales, on the one hand, and the low scores on the empathy scale, on the other hand, suggests several possible reasons for these results, from the question of the content validity of the scale for this age at which it was applied to the insufficient self-criticism of adolescents in assessing their own competencies at the interactive scale items.

Differentiation of emotions is necessary, but not sufficient for interactivity. It implies the capacity and the desire to truly understand the emotions of others, which our examinees manifest at a relatively low level. This indicates the need for further research in order to clarify this result.

\subsection{Emotional literacy in relation to years of age and the level of education}

Differences in the components of emotional literacy were also analyzed in comparison with the age of the examinees.

The results given in (Table 3 ) show interesting results. The scores on the emotional numbness scale (EN) and interaction scale (IA) of younger and older examinees are mutually similar and their scores concerning the scales of emotion differentiation (DF) and empathy (EM) are statistically significantly different.

Table 3. Differences in the level of emotional literacy in relation to the age

\begin{tabular}{cccccc}
\hline $\begin{array}{c}\text { Components } \\
\text { Scale }\end{array}$ & School & $\mathrm{M}$ & $\mathrm{SD}$ & $\begin{array}{c}\mathrm{t} \text {-test } \\
\text { value }\end{array}$ & $\mathrm{p}$ \\
\hline \multirow{2}{*}{ EN } & Primary & 2.19 & 1.14 & .55 & .58 \\
\hline \multirow{2}{*}{ DF } & Secondary & 2.12 & 1.28 & & \\
& Primary & 3.62 & 1.29 & -2.44 & .01 \\
\hline \multirow{2}{*}{ EM } & Secondary & 3.97 & 1.33 & & \\
& Primary & 2.89 & 1.39 & \multirow{2}{*}{3.46} & .00 \\
\multirow{2}{*}{ IA } & Secondary & 2.39 & 1.25 & & \\
& Primary & 3.41 & 1.49 & .13 & .89 \\
\hline & Secondary & 3.39 & 1.41 & & \\
\hline
\end{tabular}

This direction in the differences between ages is interesting for further analysis. Older students generally have higher scores on the scale of differentiation, and younger students have higher scores on the scale of empathy. In both cases differences are statistically significant $(\mathrm{p}<0.01)$.

\subsubsection{Differences in the level of emotional numbness (EN) in relation to the level of education}

The average values on the scale (EN) for both ages (Table 3 ) show that older students achieve slightly lower results on the scale (EN) and that this difference is not statistically significant. These data, together with the data about sex differences on the same scale, imply that a traditional "emotional pattern" - the suppression of emotions among boys - basically does not change with age. These data show that the reason for this phenomenon is not developmental, but based on cultural and educational factors active in childhood and evidently difficult to change.

\subsubsection{Differences in the level of differentiation of emotions (EN) in relation to the age}

On the scale of differentiation of emotions (DF), students of both ages achieved high scores (Table 3 ). The obtained data - that the results of older students are higher $(\mathrm{M}=3.97$, $\mathrm{SD}=1.33$ ), and that the differences between ages are statistically significant $(p<0.00)$ speaks in favor of the development of this component of emotional literacy with the age of students. When we interconnect the results of this component, given the significance of sex and age differences, it can be concluded that the differentiation of emotions is the highest among girls at secondary school age, and the lowest among boys of elementary school age. By comparing the values for subgroups within the sex and age variables(Secondary, $\mathrm{M}=3.97$, $\mathrm{SD}=1.33$; Female, $\mathrm{M}=3.96, \mathrm{SD}=1.32$ ), we can see that for the recognition and interpretation of one's own and other people's emotions, the key factor is the age, although the sex differences are important.

\subsubsection{Differences in the level of empathy in relation to the age}

On the empathy scale (Table 3), age differences are statistically significant $(p<0.01)$ in favor of younger students. The fact that younger students are significantly more empathic than the older students was unexpected and it is one of the most interesting findings of this research. This finding should also be checked on a representative sample to deter- 
mine whether it is a possible systematic trend, or an artifact, generated by some other reason, for example by the sample on which the survey was conducted.

\subsubsection{Differences in the level of interaction in relation to the age}

On the scale of emotional interaction (Table 3), the difference between primary and secondary school students was not observed (Primary, $\mathrm{M}=3.41, \quad \mathrm{SD}=1.49$; Secondary, $\mathrm{M}=3.39, \mathrm{SD}=1.41$ ). A slightly higher interactivity score was recorded among primary school pupils, which suggests a similarity with the lower level of empathy among secondary school pupils, compared with the primary school students.

\section{DISCUSSIONS}

Emotions are an important component of human life, and therefore each person needs to develop competencies that are related to recognizing and managing emotions, effectively resolving emotional conflicts, and establishing close, positive relationships with other people. Although it can be learned and improved throughout a person's life, the early childhood is considered to be the best period for the development of the emotional literacy.

Considering the fact that the field of emotional intelligence and emotional literacy is still a new area, not thoroughly researched and understood, and that there are not many relevant empirical research studies in Serbia, the aim of our research was to initially map emotional literacy of students and discover some of the characteristics of its key components related to sex and age.

Research results that are interpreted according to the Claud Steiner's theoretical model have shown that the students in general have an average level of emotional literacy. The results of the analysis of the subcomponents of emotional literacy by sex suggest that girls generally show a higher level of emotional literacy compared to boys, which is manifested through: a higher level of differentiation of emotions and interactions, as well as through lower scores on the absence of an emotional reaction. The results showing the level of the empathy are generally low and sex differences are not significant in this area.

Furthermore, the analysis of the results by the age of the examinees shows statistically significant differences in the opposite direction between the two components. That is to say, older students have a higher level of differentiation of emotions and a lower level of empathy than younger students.

The finding that might be especially interesting as a base for the future research is the data of the survey that high school students show a significantly lower degree of empathy compared to elementary school students. This age inversion tendency raises a number of questions: what are the reasons for relatively low level of empathy among students in general? What is the cause of the lower level of empathy among older students? What factors have contributed to it? We think that the answers to these questions should be sought in the next research in conjunction with the contextual factors of social transition, general social crisis, anomia and the value crisis in society, as well as with the specificities of the psychosocial age of older examinees - characterized by the development identity crisis (Erikson, 2008).

Another data that requires further and more detailed analysis is a conclusion of this research that a large number of students, especially boys, exhibit the signs of emotional indifference and suppression of emotions.

The overall results of the research support the need for monitoring the emotional development of young people, new and more comprehensive research, as well as a systematic influence on the development of their emotional competences, which requires a more active role of the school.

\section{CONCLUSIONS}

If the imperative of modern education is a modern, humane and more efficient school, which takes the real life forces of the child as its starting point and is entirely focused on areal, authentic student with his or her actual capacity for development, needs, interests and development problems (Kostović, 2006), this kind of school actively participates in the development of the emotional literacy of its students.

What are the chances that the emotional literacy of students becomes integral part of the educational process? Will emotions finally get legitimacy in educational discourse? Is there room for realistic optimism? Those questions are still open for all professionals in education in our country.

The facts about educational practice 
in Serbia show that socio-emotional learning programs have not yet found their place, although education experts agree that educational outcomes should not only be academic, but also social and emotional, and that much of the existing and growing problems are students and teachers are, by their nature, affective.

In countries that have recognized the importance of emotional literacy and already have a wealth of experience in this regard, the main focus is on the development programs of emotional and social competence in children and young people (SEL programs). Such programs are usually aimed at acquiring knowledge, attitudes and skills related to the recognition and management of emotions, social relations and relationships and effective decision-making (Munjas, Samarin and Takšić, 2009; Zins and Elias, 2006). Some of the programs are more general and integrated into educational curricula, while others are specific and targeted at particular problems and challenges that young people face (e.g.: Programs for the promotion of mental health; Programs for the prevention of abuse of psychoactive suspensions; Programs for the prevention of asocial behavior, school absenteeism and substance abuse; Programs for the promotion of academic success and learning; Programs for the positive development of young people. (Marić, Jurišin and Kostović, 2016). Experiences and good practice models in the aforementioned preventive and curative intervention programs could be a support in the creation of such programs in our country.

When creating and introducing these programs, it is necessary to acknowledge the fact that the teacher is a key link in the functioning of the school and that his or her role is crucial in the "bringing to life" of contemporary theories and curricula in direct practice. Research also provides useful guidelines in this field, pointing out that it makes sense to first help the teachers to become "emotionally literate" (Jennings and Greenberg, 2009). Vocational and professional training programs for teachers are primarily based on training the practitioners to recognize emotional factors that influence student behavior and to choose appropriate actions that will contribute to creating a more favorable emotional climate in the classroom, and thus to a better school achievement of students (Perry and Ball, 2007; Keener et al., 2007; as cited in Pantić, 2009).

The resources and time are needed for any change in education. Various experiences of innovation in education confirm that it is not enough just to introduce a change, but it is necessary to understand and accept the reasons for its introduction. If the teachers do not accept the educational innovation and incorporate it into their personal and professional identity, the chances for its success are, quite certainly, considerably weakened.

We believe that our research of the characteristics and level of emotional literacy of students contributes to understanding the importance of this topic in the discourse of modern school.

Although the role of the school is the most prominent, we believe that the development of emotional literacy should be more widely understood as the responsibility of all institutions and individuals working with children and young people (families, educational authorities, governmental and non-governmental organizations and wider community) in particular those whose professional interest is to provide assistance and support in their growth and development.

\section{ACKNOWLEDGEMENTS}

The paper is written as a result of the research within the Project 'Quality of Education System of Serbia in the European Perspective (KOSSEP)' (no.179010), which has been financed by the Ministry of Science and Technological Development of the Republic of Serbia.

\section{Conflict of interests}

The authors declare no conflict of interest.

\section{REFERENCES}

Bocchino, R. (1999). Emotional literacy: To be a different kind of smart. Corwin Press.

Buljubašić-Kuzmanović, V. (2008). Odnos emocionalne pismenosti i ponašanja učenika [Relationship between emotional literacy and student behavior]. Odgojne znanosti, 10 (2 (16)), 301-313. Available at: https://hrcak.srce.hr/29571

Djermanov, J., Kostović, S., Kosanović, M., \& Vukičević, J. (2015). New forms of communication as constituents of literacy: implications for education. People: International Journal of Social Sciences, 1(1). Available at: https://www. grdspublishing.org/index.php/people/article/ view/376

Durlak, J. A., Weissberg, R. P., Dymnicki, A. B., Taylor, R. D., \& Schellinger, K. B. (2011). The impact of enhancing students' social and emotional learning: A meta-analysis of school-based universal interventions. Child development, 82(1), 405-432. https://doi.org/10.1111/j.1467- 
$8624.2010 .01564 . x$

Elias, M. J. (2006). The connection between academic and social-emotional learning. The educator's guide to emotional intelligence and academic achievement, 4-14. Available at: http://insight. bostonbeyond.org/wp-content/uploads/2017/05/ Elias-2006.pdf

Erikson, E. H. (2008). Identitet $i$ životni ciklus. Beograd: Zavod za udžbenike./ Identity and the Life Cycle. (1994). WW Norton \& Company.

Figueroa-Sánchez, M. (2008). Building emotional literacy: Groundwork to early learning. Childhood Education, 84(5), 301-304. https://doi.org/10.10 $80 / 00094056.2008 .10523030$

Goleman, D. (2006). Emocionalna inteligencija. Zagreb: Mozaik knjiga.

Golub, T., \& Bohač, I. (2015). Povezanost emocionalne inteligencije i učiteljske samoefikasnosti. Conference - Researching Paradigms of Childhood and Education - UFZG2015 (pp. 163-174). Zagreb: The Faculty of Teacher Education. Available at: http://bib.irb.hr/datoteka/758239. Ljubin_Golub_Povezanost_emocionalne inteligencije i uiteljske samoéfikasnosti.pdf

Humphrey, N., Curran, A., Morris, E., Farrell, P., \& Woods, K. (2007). Emotional intelligence and education: A critical review. Educational Psychology, 27(2), 235-254. https://doi. org/10.1080/01443410601066735

Immordino-Yang, M. H. (2011). Implications of affective and social neuroscience for educational theory. Educational Philosophy and Theory, 43(1), 98-103. https://doi.org/10.1111/j.14695812.2010.00713.x

Immordino-Yang, M. H., \& Damasio, A. (2011). We feel, therefore we learn: The relevance of affective and social neuroscience to education. Mind, Brain, and Education: Implications for Educators, 5(1), 115-133. https:// doi=10.1.1.454.292 $6 \&$ rep $=$ rep1\&type $=$ pdf \#page $=115$

Jennings, P. A., \& Greenberg, M. T. (2009). The prosocial classroom: Teacher social and emotional competence in relation to student and classroom outcomes. Review of educational research, 79(1), 491-525. https://doi. org/10.3102/0034654308325693

Kostović, S. (2006). Škola na putu ka» Evropi znanja «. Evropske dimenzije promena obrazovnog sistema u Srbiji-Zbornik radova, knjiga, 2, 33-44.

Marić Jurišin, S., \& Kostović, S. (2016). "Vaspitljivost emocija": Prema "emocionalno pismenoj školi". Godišnjak Filozofskog fakulteta u Novom Sadu, XLI-2, 185-201. https://doi: 10.19090/ gff.2016.2.185-201

Munjas Samarin, R., \& Takšić, V. (2009). Programi za poticanje emocionalne i socijalne kompetentnosti kod djece i adolescenata [Programs for stimulating emotional and social competence in children and adolescents]. Suvremena psihologija, 12(2), 355-370. Available at: https://hrcak. srce.hr/82959

Oksuz, Y. (2016). Evaluation of Emotional Literacy Activities: A Phenomenological Study. Journal of Education and Practice, 7(36), 34-39. Available at: https://eric.ed.gov/?id=EJ1126517

Orbach, S. (2000). Towards emotional literacy. Health Education, 100(6), 269-270. https://doi. org/10.1108/he.2000.100.6.269.2

Pantić, J. (2009). Emotional intelligence in education. Norma, 14(1), 77-87. Available at: http://scindeks-clanci.ceon.rs/data/pdf/03537129/2009/0353-71290901077P.pdf

Park, J. (1999). Emotional literacy: Education for meaning. International journal of children's spirituality, 4(1), 19-28. https://doi. org/10.1080/1364436990040103

Perry, C., \& Ball, I. (2007). Dealing constructively with negatively evaluated emotional situations: The key to understanding the different reactions of teachers with high and low levels of emotional intelligence. Social Psychology of Education, 10(4), 443-454. https://link.springer.com/ article/10.1007\%2Fs11218-007-9025-Z

Schutz, P. A., \& Lanehart, S. L. (2002). Introduction: Emotions in education. Educational Psychologist, 37(2), 67-68. https://doi.org/10.1207/ S15326985EP3702 1

Sharp, P. (2001). Nurturing Emotional Literacy: A Practical Guide for Teachers, Parents and Those in the Caring Professions. Health Education, 101(6), 292-294. https://doi.org/10.1108/ he.2001.101.6.292.1

Steiner, C. (2003). Emotional literacy: Intelligence with a heart. Personhood Press. Available at: https://books.google.rs/books?hl=sr\&lr=\&id= WglQfhXCc54C\&oi $=$ fnd\&pg $=$ PR $8 \& d q=$ Stei ner, + C. $+(2003) .+$ Emotional+Literacy\%3B+In telligence + with $+\mathrm{a}+$ Heart. + Personhood + Press. \&ots $=$ SfkMBfACvN\&sig $=$ A4iJZ33DAJoMli $\mathrm{O} \mathrm{K}$ v i j A V Z 5 Q Q w \& r e d i r $\mathrm{esc}=\mathrm{y} \# \mathrm{v}=$ onepage $\& \mathrm{q} \& \mathrm{f}=$ false

Stepanović, J., \& Đurmanov, J. (2015). Pedagogical Climate in the Context of Improving the Process of Education. Život $i$ škola: časopis za teoriju i praksu odgoja i obrazovanja, 61(2), 183-191. Available at: https://hrcak.srce.hr/162169

Suzić, N. (2002). Emocije i ciljevi učenika i studenata. TT-centar.

Tošić-Radev, M., \& Pešikan, A. (2017). 'Komadić koji nedostaje' u procesu obrazovanja-socioemocionalno učenje. Nastava i vaspitanje, 66(1), 37-54. doi:10.5937/nasvas 1701037T

Vygotsky, L. S. (1986). Thought and language. Cambridge, MA: The MIT Press.

Wells, J., Barlow, J., \& Stewart-Brown, S. (2003). A systematic review of universal approaches to mental health promotion in schools. Health Education, 103(4), 197-220. https://doi. org/10.1108/09654280310485546

Zins, J. E., Bloodworth, M. R., Weissberg, R. P., \& Walberg, H. J. (2004). The scientific base linking social and emotional learning to school success. Building academic success on social and emotional learning: What does the research say, 3-22. Retrieved from: https://books.google. $\mathrm{rs} /$ books?hl=sr\&lr=\&id=MuDGDHCb iwC $\& \mathrm{o}=$ fnd \&pg $=$ PA $3 \& \mathrm{dq}=$ Zins,$+\mathrm{J} .+\mathrm{E} .,+\overline{\mathrm{Bl}}$ lood worth, + M.+R.,+Weissberg, + R. + P., $+\% 26+$ W alberg, + H. + J.+(2004). + The + scientific + base + linking + social + and + emotional + learning $+\mathrm{t}$ $\mathrm{o}+$ school + success. + In + Zins,,+ J. + E.,+ Weissb erg, + R.+P.,+Wang,,+ M.+C.,+Walberg, + H.+J $.+($ Eds. $),+$ Building + academic + success + on + socia\&ots $=o H 9 y h f R z B 1 \&$ sig $=$ mHcMQTh8n D s X v b m o-W x W j F X Q t w \& r e d i r $\mathrm{esc}=\mathrm{y} \# \mathrm{v}=$ onepage \&q\& $\mathrm{f}=$ false

Zins, J.E., \& Elias, M.J. (2006). Social and emotional learning. In G.G. Bear \& K.M. Minke (Eds.), Children's needs III: Development, prevention, and intervention (pp. 1-13). Bethesda, 
(IJCRSEE) International Journal of Cognitive Research in Science, Engineering and Education Vol. 6, No. 2, 2018.

MD: National Association of School Psychologists. Available at: https://static1.squarespace. com/static/5622d9f6e4b0501d4068d092/t/58 $597 \mathrm{c} 0 \mathrm{cbebafbe} 1334 \mathrm{eb} 638 / 1482259468882 /$ Elias_\%26_Zins\%2B2006.pdf 